\title{
STATE TRADING IN HISTORY AND THEORY*
}

\author{
John N. Hazard $†$
}

State conduct of foreign trade is a major concern of midcentury economists, lawyers, government officials, and private merchants. Its most ardent opponents have suffered defeats, and even the United States Government is considering resort to it as an instrument of the cold war. Writing in December 1958, James Reston, of The New York Times, has found it possible to quote an anonymous high official in Washington in a warning,

We have been discussing quietly inside our own Government for six months the need to establish an overseas trade monopoly to compete with the Soviet monopoly on equal terms, but this is so foreign to our normal way of doing business that we dare not mention it in public.

International conferences of governments ${ }^{2}$ and of individual scholars ${ }^{3}$ have been wrestling with the unresolved problems presented by the expansion of state trading. The concern of theoreticians and practical men alike is mounting, and the problems are many, as evidenced by the articles in this symposium devoted to the subject. What began to be important years ago, but without attracting attention, has been brought since World War II to the front lines of the clash of ideologies between the privateenterprise economies and those flying the flag of communism. Today, officials even of the major bastion defending the private-enterprise system are contemplating risking a hole in the walls to compete more effectively with Soviet traders seeking to expand the influence of the Soviet Union and of Communist China throughout the world.

The problems of today are far from those of the early Middle Ages, when state trading may be said to have been born. An economist has written that, "the trade of Venice was organized upon a political basis. It could almost be said that the Venetian state was a company of merchants of whom the Doge was the chief."

The history of the intervening centuries ${ }^{5}$ is not the concern of those seeking

* The author wishes to express appreciation for bibliographical aid in the preparation of this article rendered by Dr. Martin Domke, of the American Arbitration Association, and Miss Ruth Savord and Mr. Donald Wasson, of the Council on Foreign Relations in New York.

† B.A. 1930, Yale University; LL.B. I934, Harvard University; Certificate 1937, Moscow Juridical Institute; J.S.D. 1939, University of Chicago. Member of the New York bar; Professor of Public Law, Columbia University. Adviser on State Trading, Commercial Policy Division, United States Department of State, x945-46. Author, Law and Social Change in the U.S.S.R. (1953), The Soviet System of GOVERNMENT (1957).

1 Reston, Trade Policy Quandary, N.Y. Times, Dec. 2, 1958, p. I7, cols. 3-5.

${ }^{3}$ See U.N. Doc. No. E/ECE/270, pt. I (1957).

${ }^{3}$ See Harold J. Berman, Meeting of Jurists on Peaceful Cooperation, final Report (Doc. No. UNESCO/SS/Coop/Inter I, annex III) (1958).

'Huntley M. Sinclair, The Principles of International Trade 14 (I932).

'See Clive Day, A History of Commerce (4th ed. I938); also Asher Isaacs, International Trade, Tariff, and Commercial Policies (r930). 
a trace of state trading, for they witnessed the predominance of private merchants, working to further their private interest through devices such as the fairs, the Hanseatic League, and finally the great companies with fighting forces and quasisovereign power. The state taxed and even designated the regions of trade. Its explorers opened new continents, and its galleons protected the trade routes; but it was not itself the monopoly buyer and seller with which state trading is today associated. It was not until the industrial revolution had become far advanced, with the attendant concern of economic theorists for new methods to cope with its aftermath, that state trading appeared as a panacea. It was linked with other elements of a strengthened state in the minds of those who called themselves socialists, as part of their plan for economic development under state auspices. The disciples of "laissez faire" remained so numerous, however, and the expanding capitalist economy so fruitful that it was the scholar, and not the government official, who bothered with such ideas.

World War I brought an end to many dreams, among them the possibility of winning a war without mobilizing the key elements of the economy as well as its military forces. Englishmen and finally Americans had to abandon their concept of "laissez faire" in certain areas to meet the demands of the crisis. Economists have noted that familiar views persisted, but practice changed perceptibly, so that the state's role was enlarged, despite formal obeisance to liberal principles. ${ }^{6}$ Purchasing missions on government account appeared in the great markets of the world. The Tsar of Russia bought munitions in the West, and the firm of Morgan financed the French Government in its commercial operations in the United States. The retreat from private enterprise was not limited to the Continent. The United States thought it necessary to requisition the railways and to form a commercial fleet to be managed by the War Shipping Board. Yet, governments still relied upon the price system to obtain the goods they required. The War Shipping Board waived its right to claim sovereign immunity in the courts. " "Business as usual" is said to have "expressed not only one's patriotic duty, but also abounding faith in the transitory character of the whole episode."8

With the ending of World War I, the popular slogan of the time was "back to normalcy," and for the Western world, state trading was laid to rest as a necessary evil of wartime, to be discarded as soon as international trade could be restored to the long-proven methods of the private merchant, moving alone or in concert with his fellows, about the markets of the world. State trading reverted to secondary consideration, as an inconsequential mechanism of the commerce of the world, useful to some nations seeking revenue for depleted treasuries through tapping the pockets of salt-eaters, liquor-drinkers, and smokers via almost traditional state monopolies

\footnotetext{
${ }^{8}$ See Norman S. Buchanan \& Friedrich A. Lutz, Rebuilding the World Economy: America's Role in Foreign Trade and INVestMent 27 (1947).

${ }^{7}$ See The Florence H., 248 Fed. I012 (S.D.N.Y. Igr 8 ).

${ }^{8}$ Buchans \& LuTz, op. cit. supra note 6 , at 27 .
} 
of salt, liquor, tobacco, and matches. State trading was not generally expected to be: important on any grander scale. ${ }^{9}$

Into this commonly-accepted school of thought, which viewed state trading as: an instrument in the arsenal of war, except for the occasional revenue-producing. tobacco, salt, or liquor monopoly, was thrust quite a different theoretical approach by the Russian Revolution of IgI7. At first, the new approach caused little alarm. The whole revolution seemed to be a transitory phase, which could be quarantined until it collapsed of its own weight or was conquered by elements loyal to the prerevolutionary regime, helped at places by the Western powers.

Vladimir Ilyich Lenin, as the theoretician of the Russian Revolution, set the stage for what was to follow. He declared, ${ }^{10}$

Strengthen and regulate those state monopolies, which have already been put into effect and then prepare the monopolization of foreign trade by the state; without this monopolization we shall not be able to separate ourselves from foreign capital and from paying tribute.

In this concept, state trading became a companion of state production. Both seemed. necessary to Lenin to achieve an economic organization suitable to the creation of a. socialist and ultimately a communist society.

Lenin was not unchallenged, even within his own Communist Party, for some of his colleagues thought that in the early stages of the new Soviet society, the new Soviet state could protect its infant state industries as other nations protected their infant private industries-namely, by high tariffs. He lashed out at Nikolai Bukharin to say, ${ }^{11}$

Bukharin does not see that no policy of tariffs can be effective in the imperialist epoch. when there is a monstrous difference between the poor countries and those of unbelievable wealth. Bukharin refers to protection by tariffs, failing to see that under the conditions referred to any one of the wealthiest countries can break down this protection.

The spectre of a giant cartel willing to sell its goods in the Soviet market at cut prices so as to dominate the new Soviet state producers, even under a tariff set at previously unimagined heights, haunted Lenin. Fearful as he was that the capitalists sought not only to expand sales in the new Soviet market, but even to undermine the Bolsheviks by weakening their economic power, Lenin was strong in his determination to foster state trading. He was doing more than protecting infant industries. He was preparing the way for an infant society which he expected eventually to mature so as to win domination of the world. In this situation, state trading was an instrument of the new Messiah, and its place in the Soviet arsenal of

\footnotetext{
'Jacob Viner has expressed doubt that the League of Nations' Committee for the Study of the Problem of Raw Materials (1937) acted properly in excluding examination of tobacco monopolies because they fell within the sphere of internal policy. He thinks the purchasing practices of fiscal monopolies which are important purchasers of foreign commodities legitimate subjects of concern to other countries. Sec Jacob Viner, Trade Relations between Free-Market and Controlled Economies 7 I-72 (League of Nations Pub. No. 1943. II. A. 4).

${ }^{10} 22$ V. I. Lenin, Sochinenila [Collected Works] 449 (3d ed. 1928-37).

1127 id. at $38 \mathrm{x}$.
} 
weapons was protected with all the emotion of one whose aim was world salvation, not the narrower goal of economic profit. Only in this light can the Leninist position be evaluated. No concession to Soviet power would loom large enough in Lenin's eyes, nor in the eyes of those who have followed him, to be worth even partial abandonment of the state monopoly of foreign trade.

It is against such a background that state trading was created by law as one of the pillars of the new Soviet state. Lenin's decree of April 22, I9I8 declared, ${ }^{12}$

All foreign trade is nationalized. Contracts for the purchase or sale of all kinds of products (the products of mines, of industry, of agriculture and others) with foreign governments or individual enterprises abroad will be carried out in the name of the Russian Republic by specially empowered organs. Apart from these organs every contract for trade, for purchase or sale abroad is forbidden.

Stalin repeated Lenin's adamant position in defense of state trading at the height of the New Economic Policy when an American delegation asked why he felt it necessary to adhere to it at the same time that a neocapitalism had been authorized for the domestic economy. In his retort, he said, ${ }^{13}$

the abolition of the monopoly of foreign trade would mean a retreat from the industrialization of the country, from the construction of new plants and factories, from the repair of new plants and factories. This would mean for them the submergence of the U.S.S.R. by goods from capitalist countries, the warping of our industry by virtue of its relative weakness, an increase in the number of unemployed, a decline of the material position of the working class, and a weakening of its economic and political position.

Stalin was thinking still in terms of protection of the new Soviet system from enemies from without. He had not yet had the vision of state trading as a mighty weapon in the struggle for men's minds throughout the world. When he sold lumber or coal at dumping prices in foreign markets, he sought to get much-needed foreign exchange so that he might buy precious foreign machines to modernize his factories. He was not seeking to enter the foreign markets with a wedge to be expanded later by political methods when the time was ripe. Not until after World War II did this possibility open to Soviet leaders, to be exploited by Nikita Khrushchev with such effectiveness that state trading became of concern not only to private merchants seeking to save their hard-earned places in foreign markets, but to foreign office officials seeking to maintain alliances or to encourage neutrality in the midcentury conflicts conducted on the governmental level to win friends. ${ }^{14}$

For the private-enterprise countries entering upon the interwar years, state trading was as strongly opposed by the vocal elements as it was praised by the Soviets. Private commerce between nations had to be restored to vigor. In this process, the state had a duty to seek out markets for its merchants, even to create commercial

\footnotetext{
12 [1918] Sob. Uzak. RSFSR, No. 23, item 432.

${ }^{13}$ J. V. Stalin, Conversation with the First American Workers' Delegation, Sept. 9, 1927, in Voprosy Leninizma [Questions of Leninism] I79 (roth ed. 1933).

${ }^{14}$ For an account of Soviet policy, as evidenced by trade statistics and reports, see JosEPH S. BERLINER, Soviet Economic Aid: The New Aid and Trade Policy in Underdeveloped Countries (i958).
} 
counselors in its embassies abroad to study markets and report back to boards of trade and departments of commerce what seemed to be a good place to sell or to buy. Yet, this was not state trading. The United States Government was not itself to buy olive oil in Italy for sale in New York on the open market.

This view of the desirability of state withdrawal from participation in foreign commerce, except as an aid to private merchants, was shaken, however, with the Depression. There appeared practical men who began to think of state trading not in Soviet terms of a means to further state absorption of the domestic producer and in aid of state economic planning, but rather as a means of improving comparative advantage in international trade. Bulk buying was seen as a means of obtaining low quotations from producers dazzled by enormous orders. State trading provided the opportunity to increase the size of the orders placed abroad. In a world in which currencies were becoming blocked in increasing numbers, state trading facilitated the execution of barter deals through which critical materials could be obtained without use of foreign exchange at all. Many decried these departures from the classical form of international commerce, but to these critics there was the reply that the crisis of the Great Depression was as much of a challenge as a war, and departure was justified to save the state. It would be only a temporary expedient until business could be resumed as usual.

A new element entered the debate, however, for in contrast to the war period, there were now analysts who were not so sure that state trading was to be only a temporary expedient. Charges began to be hurled against the state traders of the private-enterprise world that they were but wolves in sheep's clothing. Some critics feared that under the guise of temporary expediency, proponents of state trading were seeking to prepare the way for ultimate introduction of a socialist system which only a small minority would favor if they could understand what was happening.

Into this scene of growing scepticism of expressed motives came World War II. The private-enterprise countries girded for action, and again they turned to state trading, but they sought to avoid some of the practices of World War I. The United States nationalized no railways, although it did requisition ships. This time, private enterprisers were, wherever possible, to remain as administrators, and the state was to serve only as coordinator in the war effort, setting priorities, establishing fixed prices, fixing specifications, and even dictating order boards, but not itself being the entrepreneur.

To this policy of restraint, there were exceptions in critical areas. ${ }^{15}$ In the United States, the production of synthetic rubber became a state monopoly, and the secret manufacture of atomic fuels was, of course, a state activity. In the foreign trade area, the state also found it necessary to participate directly to keep critical materials from the hands of the enemy when these materials appeared on foreign markets. ${ }^{16}$

\footnotetext{
${ }^{16}$ See Stephen Enke \& Virgiz Salera, International Economics 437 et seq. (I95I).

${ }^{10}$ Sec Foreign Economic Administration, Report to Congress on Operations 15 (1944).
} 
Only a government could function in the neutral Turkish market to keep the Germans from buying hazel nuts from which they could extract precious oil for mechanical fuses. Each of the foreign powers buying in the American market to equip their military machines created purchasing commissions which acted for the state in obtaining the sinews of war.

The United Kingdom established a pattern with its United Kingdom Commercial Corporation, through which it conducted preclusive buying operations to hamper the enemy, and with its British Purchasing Commission in Washington, it created a headquarters for its war purchasing effort, as did the other allied powers. The last of these to be formed was the Government Purchasing Commission of the U.S.S.R. in the U.S.A. ${ }^{17}$

Those who had studied Soviet practices saw in this last something of a different organization than the agencies called purchasing commissions created by the other powers. Ever since United States recognition of the Soviet Union in 1933, the Soviet authorities had been hoping to establish in the United States an agency similar to that established in most other countries with which the Soviet Union had diplomatic relations-namely, a state-trading delegation. This desire had been resisted by United States Government authorities because it would have involved recognition of some measure of diplomatic status for the commercial agents of the Soviet Union who would comprise its staff. In every country in which Soviet statetrading delegations had been established, the Soviet authorities had requested diplomatic standing for the chief of the delegation, immunity of the premises, the right to use cipher, and immunity from suit. In each case, the establishment had been completed under the terms of a commercial treaty setting forth the extent to which the receiving power was willing to accede to Soviet requests. ${ }^{18}$ The authorities of the United States wanted none of this, for they felt that the delegation would be an entering wedge for state trading within the American market, and they feared that pleas of immunity might create a situation from which American merchants could be exploited. ${ }^{\mathbf{1 9}}$

In view of United States Government refusal even to consider the presence of a Soviet trade delegation in Washington, the Soviet authorities had been forced to content themselves with continuation of a device established in 1924, during the period of nonrecognition of the Soviet Government, to serve as an agency through which trade with the Soviet Union could be carried on. It took the form of a New York corporation, entitled the Amtorg Trading Corporation, in which Soviet Foreign Trade Ministry officials held all the stock, but which, as a domestic corpora-

\footnotetext{
${ }^{17}$ For an account of the United States-Soviet Union relationship, see E. R. STETrINIUS, JR., LENDLEASE, WEAPON FOR VICTORY CC. I9-20 (I944).

${ }^{18}$ For examples of the provisions of such treaties, see $T$. A. Taracouzio, The Soviet Union AND INTERNATIONAL LAW 182, I83 (1935).

${ }^{10}$ An example of nongovernmental thinking at the time of recognition of the Soviet Union by the United States is to be found in American Foundation, The United States and the Soviet Union: A Report on the Controlling Factors in the Relation between the United States and the SOVIET UNION (1933).
} 
tion, was subject to all New York laws. There could be no thought of immunity, either in court or to state or federal regulation.

The war situation presented the Soviet Government with an opportunity for change. They began their purchasing for war purposes in the United States after the German attack upon them. As a result of the German attack, the prohibitions of the Hitler-Stalin Pact era were lifted in the United States, and the Amtorg Trading Corporation began to function vigorously again. When the Soviet Union was declared a beneficiary of the Lend-Lease Act on November 7, I94I by President Franklin D. Roosevelt, ${ }^{20}$ the Amtorg mechanism soon evidenced its inadequacy for the new, greatly increased supply task which it was called upon to perform. Edward R. Stettinius, as Lend-Lease Administrator, called in the Amtorg officials, together with the officials of the Soviet Embassy, and advised that a purchasing commission more nearly in the form of those established by the other allied powers be created so that there might be within it Army and Navy supply officers, and not just the peacetime commercial agents of the Soviet Ministry of Foreign Trade. The last had shown themselves incapable of casting aside the peacetime restrictions placed upon them by strict Soviet laws requiring minute inspection of every item and unceasing negotiation for lower prices; yet, a less commercial attitude was necessary if the goods were to be moved swiftly in the vast quantities required by war.

Soon after the establishment of the new Soviet Government Purchasing Commission in Washington, a Soviet Major General of the Air Force and a Soviet Vice Admiral who was a specialist on munitions arrived to assume its direction, but some of the former Amtorg officials remained at their sides. All were subordinate to the long-time specialist on foreign trade in Moscow-namely, Anastas Mikoyanand he soon tried out his luck. He sent his subordinates to see Mr. Stettinius with the request for information as to whether it could be anticipated that the Purchasing Commission might become after the war a Soviet state-trading delegation. After consultation with the permanent United States Government agencies concerned with peacetime commerce, Stettinius had to inform his questioners that it was not anticipated that the United States Government would look with favor after the war upon the establishment of any state-trading delegations in the United States, and the matter was not raised again.

While indicating its dislike of state-trading mechanisms, the United States Government found itself drawn increasingly into such operations. To conduct its preclusive buying operations in concert with the British, it created a United States Commercial Corporation. ${ }^{21}$ This state-trading agency was assigned the task of buying essential raw materials available in countries accessible to Germany-namely, Turkey, Spain, and Portugal. For administrative purposes, it was made subordinate to the Board of Economic Welfare, and as such, it was transferred to the Office of Economic

${ }^{30} 55$ STAT. $3 \mathrm{X}(194 \mathrm{r})$. (1953).

21 Sec Henry Chalmers, World Trade Policies: The Changing Panorama, i920-1953, at 273 
Warfare when the Board was abolished in 1943. Later in the same year, it passed to the Foreign Economic Administration when the Office of Economic Warfare was absorbed by it. ${ }^{22}$

Not all state trading was in the hands of the United States Commercial Corporation, for by Executive Order of May 30, 1942, issued under the First War Powers Act, the authority previously limited to the Secretary of the Navy to make emergency purchases of war materials abroad and to have them admitted to the United States free of duty was extended to various departments and agencies of the United States Government. During the fiscal year I943-44, $\$ 800,000,000$ worth of foreign strategic materials were bought with government funds under Foreign Economic Administration direction, exclusive of the preclusive buying program. ${ }^{23}$

The United States Commercial Corporation bought materials for import under War Production Board or War Food Administration directives, and these were then allocated or sold to war industries or for other war purposes, in large part through the facilities of the Reconstruction Finance Corporation and the Commodity Credit Corporation.

The Foreign Economic Administrator, Leo P. Crowley, was kept acutely conscious of the hostility to state trading by the foreign traders and bankers of the United States, and he established an advisory committee of their representatives in an effort to reduce their fears. ${ }^{24}$ Almost all of them saw the necessity of war purchases by the state, but many had little confidence in the motives of the Roosevelt administration, which seemed to them to be utilizing the war emergency to establish a foothold for state trading as an entering wedge for socialism. The Administrator's effort to alleviate such fears was reflected in his report for 1944 , in which he added a line to his account of the United States Commercial Corporation. He said, "The facilities and services of private importers were utilized at some stage of practically all Foreign Economic Administration procurement operations." ${ }^{\text {"25 }}$ Later in the report, he stated that the policy followed in foreign procurement has been to have the United States Government engage in actual procurement only when the required amounts of strategic commodities could not be bought effectively through ordinary commerical channels.

The back was broken by a last straw, which happened to be Italy. As Italy was overrun by allied troops, it seemed obviously desirable to utilize some of her strategic resources by purchasing them for the allied war effort; but it was also desirable from a strategic point of view to aid in restoring the Italian economy so that economic dislocation would not hamper the allied cause among people behind the allied lines. This suggested purchase of other Italian commodities which were useful, but not

${ }^{22}$ For texts of the executive orders concerned, see Foreign Economic Administration, op. cit. supra note 16 .

${ }^{23}$ See id. at 22.

${ }^{24}$ Some of the concerns are reflected in UNited States Associates, International Chamber of Commerce, Incorporated, Relations pith State Trading Nations (x948). Also see Chalmers, State Trading in Europe: Its Status and Prospects, J. Int'l Economy, Nov. Io, 1945, p. 3.

${ }^{25}$ Foreign Economic Administration, op. cit. stipra note 16 , at 22. 
essential, to the strategic stock piles in the United States and the United Kingdom, but for which there was a market which could produce funds with which the Italians could commence rebuilding their war-torn economy.

Under this policy, there were added to the strategic materials a quantity of Italian wines, essential oils, and what the Department of Commerce experts called "a few other Italian specialties." New York private traders were soon reporting that the United States was going so far as to import Italian marble statuettes. These purchases were made by the Allied Commission in Italy and consigned to the United States Commercial Company as its agent. The strategic materials followed the usual pattern of distribution according to War Production Board or War Food Administration order, but the others were distributed among American importers for sale in the open market. The funds obtained by such sales were paid over to the United States for use of the Italian Government, less, of course, the private-trading agent's commission. In this operation, there were the to-be-anticipated charges of favoritism in the allocation of sales agencies by the United States Government to private merchants, and this was held up as a further example of the undesirability of government participation in the foreign trade operation.

President Roosevelt was fully aware of the public relations perils of his statetrading program. He had the Foreign Economic Administrator inform the French Supply Mission and the Colonial Mission in 1944 that they were expected to deal increasingly with private interests in the United States instead of with the United States Government. ${ }^{27}$ Prior to that time, the Lend-Lease procurement channels for nonmilitary items, most of which were under the Treasury Procurement Agency of the United States Government, had been buying some nonwar items for the French on a cash-reimbursable basis. This type of activity was to stop, and to make it possible to return to private channels, the Foreign Economic Administration announced in December I944 that for similar commodities and when the end use was comparable, no preference or higher priority would be given to export license applications from foreign purchasing missions than to applicants from the trade. ${ }^{28}$ This restored the American private exporters to business, for up to that time, a foreign government purchasing mission's application would have been given priority automatically.

President Roosevelt, in September 1944, showed his concern for private traders' sensibilities when he released an instruction that after the defeat of Germany, the Foreign Economic Administration "should relax controls over exports to the fullest extent compatible with our continuing war objectives . . . with a view to encouraging private trade without interfering with the successful prosecution of the war against Japan."29 This concern had been fortified by the apparent desire of some governments to carry on bulk buying or to centralize imports in other forms in the postwar period.

\footnotetext{
${ }^{30}$ See Henry Chalmers, World Trade Policies: The Changing Panorama, ig20-1953, at 304 (1953).

${ }_{27}$ Id. at $306 . \quad{ }^{28} \mathrm{Ibid} . \quad \mathrm{Id}$. at $3 \mathrm{ro.}$
} 
Bulk purchasing had emerged during the latter half of $x 944$ in fields unrelated to the war. ${ }^{30}$ The United Kingdom announced the conclusion of long-term contracts with the governments of Australia and New Zealand for the bulk purchase of the entire exportable surpluses of meats and dairy products of those countries. The arrangements were to run for from two to four years. ${ }^{31}$ Nearly similar arrangements were made with Canada, and the British Ministry of Food announced that it contemplated extending this policy to Argentina and other South American countries. The reason was given that the United Kingdom Government was making these bulk-purchase agreements "as part of its policy for safeguarding food supplies for the United Kingdom for the next few years." The British policy was being opposed, however, by some Englishmen because they thought that it would perpetuate undesirable principles of commercial policy at a time when it was unnecessary to replace private firms and competitive importation by governmental operations.

The United States showed its irritation with such a prolongation of state trading by a letter of President Roosevelt, dated September 29, $1944,{ }^{32}$ in which the President directed that in view of the curtailment to be made in war production after the defeat of Germany, plans should be initiated for

an appropriate cut in the foreign procurement program for strategic and critical materials needed in the prosecution of the war. The adjustment to this reduced program should be made in such a way as to prevent undue and unnecessary financial losses to American taxpayers, to best preserve our foreign relations and to strengthen the foundation for a high level of international trade in the future.

In spite of these protestations, the fact remained that during 1945, the last year of the war, the great bulk of purchases made in the United States by most of the countries of continental Europe was made through the purchasing missions, sometimes as the agents of governmental centralized buying agencies in their home capitals and sometimes as coordinators and expediters of orders of private merchants in their homelands who negotiated the purchases with American private traders but then needed help in obtaining export licenses in Washington.

True to its promise to the American foreign trade fraternity, the United States Government, in May 1946 , prepared an order ${ }^{33}$ to be presented to the foreign government purchasing commissions of Australia, Belgium, China, France, Greece, India, Italy, Netherlands, New Zealand, Norway, Poland, Portugal, Union of South Africa, the Soviet Union, and the United Kingdom asking them to limit their operations during a transitional period to the procurement of essential civilian commodities. They were to utilize normal trade channels to the maximum extent possible and to bring their purchasing methods into accord with commercial considerations. After the transitional period, they were to liquidate.

\footnotetext{
${ }^{30}$ See ENRE \& SALERA, op. cit. supra note 15 , at 443-46.

${ }^{21}$ See Henry Chalmers, World Trade Policies: The Changing Panorama, 1920-1953, at 326 (1953).

${ }^{3}$ Id. at 327 .

${ }^{38}$ See Release of May 4, I946, r4 Dep't State Bull. 819 (1946).
} 
The Secretary of State called each group of officials in turn to tell them of the policy decision and to present them with an aide memoire. In the case of the Soviet Government, since it was obvious that the Soviet Government would not abandon its state monopoly of foreign trade, the communication added that it was presumed that the Soviet Government would continue to conduct its commercial operations through a centralized agency, but that the United States Government desired that "trade between the United States and the U.S.S.R. should again be carried on by an agency or agencies incorporated in one of the states of the United States as was the case prior to the war."

American policy, in short, required return to the prewar pattern of commercial relations, even for the Soviet Union; and for the latter, it would have to channel its purchases and sales through an agency having the form of a private corporation. Within a short time, The Amtorg Trading Corporation was required to register as an agent of the Soviet Government under the terms of the Alien Registration Act. ${ }^{34}$ This identified it as governmental and provided special controls, athough it gave it no rights to claim sovereign immunity.

It seemed in 1946 , for the moment, as if state trading could be pushed back to its prewar status; but this was not to be. The various East European states, as they were brought successively securely within the Soviet orbit, declared their policy to be that of state trading. One of these, Czechoslovakia, had become a charter member of GATT in 1947 before this policy had been enunciated, and so there was a monopoly state trader within the framework of an organization primarily composed of private traders who permitted themselves to conduct some state trading, but only on a marginal basis.

The expansion of the Soviet-influenced world was bad enough to private enterprisers, but the real blow was to fall from the hands of the private-enterprise countries themselves, for by I95I, an economist was able to write, "The total amount of the world's trade that is carried on directly by governments is substantial, even if we exclude that of the socialized states."35 He noted that the United States was the only major wheat-exporting country not having a government-trading monopoly in wheat, and that bulk-purchasing agreements were being utilized by governments to acquire agricultural and numerous other types of commodities, especially raw materials important in the country's economy. He noted further that when nationalization of industry occurred, as it had occurred in the United Kingdom in the coal mines, the railways, and the steel industry, purchase and sale were necessarily through state agencies, and there was no reversal of the trend toward state trading to be expected in this area.

No more controversial agency engaged in such activity was to be found than the Argentine Trade Promotion Institute (IAPI). Until its recent liquidation, it conducted the importation of equipment for the state-owned oil business, railways, and

36 54 Stat. 670 (1940). Cf. 66 Stat. 223, 8 U.S.C. $\$ \$$ I30I-06 (I952).
35 John Parke Young, The International Economy 372 (3d ed. I95I) 
other enterprises. It also served as the import agency for the state monopoly of rubber, tinplate, oil, and coal. Its export operations involved purchase of agricultural products from Argentine farmers at low prices for resale on the markets abroad at world prices. It is even alleged that its position was strengthened by preferential exchange-rate terms on some of its transactions. ${ }^{36}$ This position had aroused the hostility of foreign private firms attempting to sell in the Argentine market.

The nationalization policies of the United Kingdom and of France have worried another economist, ${ }^{37}$ and he has concluded that World War II is bound to have had a more disturbing effect upon the world economy and international trade than World War I. He doubted that the defeated countries of Italy, Germany, and Japan would avoid state control over their economic affairs. He felt that in the countries occupied during the war, the struggle to wipe out unemployment would tempt even the governments firmly committed to private enterprise to assume unprecedented control over business activities and even, on occasion, to take a direct hand in matters affecting foreign trade. He reported that because of these developments, many are of the opinion that the trend toward direct government control over foreign trade is irresistible and that there is no alternative but to accept national controls over foreign trade. He related this to his conclusion that people are no longer willing to suffer persistent depression and mass unemployment passively, so that governments will find themselves forced to take every reasonable and even heroic measures to combat economic depression, on pain of receiving short shrift at the hands of the masses.

This pessimistic view from the point of view of the private traders is shared by other economists. One thought in I950 that the outgrowth of the industrial revolution had made apparent the need for action in the public interest, sometimes in the form of regulation and control, sometimes in the form of a laying down of rules for private enterprise, and elsewhere in the form of goods and services provided by the government itself. ${ }^{38}$ He expected that no theory would underly such extension, except in areas falling under the influence of the Soviet Union, but that in the private-enterprise countries, the extension would be made on pragmatic grounds. In short, to muddle through a crisis, government would take into its hands economic activity, and by degrees, there would be built up increasing areas of state enterprise, including state trading.

To those who view matters in this way, the report of James Reston, that to meet Soviet economic penetration of areas of the world in which Americans have hoped to see political and economic development along the lines of liberal democracy, the United States is beginning to feel the necessity of recreating the United States Commercial Corporation or some similar agency, is alarming. To meet the threat expressed by Soviet state-trading agencies, the United States sees the necessity of

\footnotetext{
${ }^{8 B}$ See ENKE \& SAlerA, op. cit. supra note I5, at 306.

${ }^{37}$ See Lawrence W. Towle, International Trade and Commercial Policy 743-45 (1947).

${ }^{38}$ See P. T. Ellsworth, The Internationaz Economy: Its Structure and Operation 443 (1950).
} 
creating its own. It is a narrow opening to which attention of this nature is now being given, but it cannot but cause fears that through the crack in the door, the wolf may squeeze.

Without a theory like Lenin's, and to cause the containment of that theory to such parts of the world as presently accept it, the United States, as the arch defender of the private trader, seems to feel itself impelled to adopt the instruments of the hostile theory. Will adoption lead to the final victory of state trading, at least in primary essentials, throughout the world? That is the question posed to the exasperated government officials in Washington as they seek to meet the Soviet successes. They want none of what might follow, but they would like to have a stronger weapon to use in their campaign against the expansion of Soviet influence. If they weaken their position against state trading for this utilitarian purpose, can they argue against the bulk purchasing of their allies of the private-enterprise world? In the answers to these questions lies the future of state trading, and with it, the future of private-enterprise commercial relations. This question is posed at a time when conservative governments have been re-emerging in various parts of the world previously thought to be moving toward socialism. The steel industry in Britain has been returned to private hands, as has road transport. France under De Gaulle may have less socialist influences governing her future. West Germany, Italy, and Japan have not moved totally in the direction of state enterprise anticipated soon after the war by the economist cited above. The Eisenhower administration has done much to check governmental development of domestic resources in the United States. To some, the tide toward socialization of the economy seems to have turned, ${ }^{39}$ and with it, the possible spread of state trading has seemed less likely than a decade ago. Yet, following upon these reversals of expectation, comes the thought of using Soviet-type weapons to fight Soviet expansion, and the matter is thrown out of balance again. Even without such a possibility, the discussion of the problems set forth in the articles to follow would be crucial to an understanding of the functioning of an important segment of the foreign trade of the world. With such a possibility, the articles take on new importance of unpredictable magnitude.

${ }^{\text {so }}$ See Sulzberger, Socialism Faces a Year of Decision, N.Y. Times, Dec. 29, 1958, p. 14, col. 4. 